\title{
PAN-AMERICAN REGIONAL WOOD ANATOMY MEETING
}

Organised by the International Association of Wood Anatomists and held in conjunction with the 36th Annual Meeting of the American Institute of Biological Sciences.

Gainesville, Florida, U.S.A., August 11-15, 1985

Convener on behalf of IAWA : Regis B. Miller

Convener on behalf of the Botanical Society of America: Elisabeth M. Lord

\section{PROG RAM}

Monday morning, August 12 - Martin H. Zimmermann memorial symposium 'Ecology and Functional Wood Anatomy' - Chairman: Philip R. Larson.

8.15 Philip R. Larson. Introduction.

8.30 Arthur C. Gibson, Howard W. Calkin and Park S. Nobel. Hydraulic conductance and xylem structure in tracheid-bearing plants.

9.00 John S. Sperry. Xylem embolism in the palm Rhapis excelsa.

9.30 Frank W. Ewers. Xylem structure and water conduction in conifers and lianas.

10.00 Break

10.30 Pieter Baas. Ecological wood anatomy of trees and shrubs from Israel and adjacent regions.

11.00 Sherwin Carlquist. Ecological wood anatomy of some southern California plants.

11.30 Discussion.

Monday afternoon, August 12 - Contributed papers on Ecological and Functional Wood Anatomy Chairman: George S. Ellmore.

1.30 David R. Dobbins and Jack B. Fisher. Regeneration after wounding in stems of lianas.

1.45 Paul M. Rich. Developmental anatomy of the stem in Welfia georgii Wendl. ex Burret, Iriartea gigantea Wendl. ex Burret, and other arboreal rainforest palms: implications for mechanical support.

$2.00 \mathrm{M}$. Wisniewski and E. Ashworth. Ultrastructural changes related to cold hardiness in cortical and xylem parenchyma cells of Prunus persica.

2.15 Sam K. Essiamah. Water uptake in deciduous trees during winter and the role of conducting tissues by the reactivation in spring.

2.30 George S. Ellmore and Frank W. Ewers. Hydraulic conductivity in trunk xylem of elm, Ulmus americana.

2.45 Break

3.00 Ann M. Lewis and Melvin T. Tyree. The relative susceptibility to embolism of larger vs. smaller tracheids in Thuja occidentalis.

3.15 Beata Zagórska-Marek. Domain dislocations in cambium of Fraxinus excelsior.

3.30 Vernon I. Cheadle and Jennifer A. Thorsch. Kinds of vessels in Eriocaulaceae.

3.45 J. Thomas Quirk. Wood anatomy of Pterocarpus and Dalbergia.

4.00 David C. Michener. Wood anatomy of Californian Penstemon (Scrophulariaceae).

4.15 Elisabeth A. Wheeler, Ronald G. Pearson, C. Anthony Lapasha, C. Webster Hatley, Thomas Zack and Alan Smith. Computer-assisted wood identification based on perforated card keys.

4.30 J. Stephen Case. Photogrammetric measurement of branching structure in trees and umbels using a microcomputer.

5.30 Reception and business meeting IAWA. Holiday Inn. 
Tuesday morning, August 13 - Contributed papers on Vascular Anatomy - Chairman: P. Barry Tomlinson.

8.30 Martin C. Goffinet, Robert M. Pool and Harriet D. Hubbard. Xylem integration between the parent cane and its elongating shoot in 'Concord' grapevines (Vitis labruscana).

8.45 Cadance A. Lowell and Terry W. Lucansky. Developmental anatomy of stems of Ipomoea quamoclit and Ipomoea hederifolia (Convolvulaceae).

9.00 P. Barry Tomlinson. Development of the leaf trace system within individual leaves of the palm Rhapis excelsa.

9.15 George J. Wilder. Stelar anatomy of first-order roots in the Cyclanthaceae (Monocotyledoneae).

9.30 Darleen A. Demason and Mark A. Wilson. The continuity of primary and secondary growth in Cordyline terminalis (Agavaceae).

\subsection{Break}

10.00 Roni Aloni and Tal Plotkin. Vessel-length distribution in the stem of Coleus.

10.15 Roni Aloni and Eliezer F. Indig. The control of vessel diameter in the stem of Luffa.

10.30 Robert D. Warmbrodt. Solute concentration in the phloem and associated vascular and ground tissues of the root of Hordeum vulgare $\mathrm{L}$.

10.45 Nels R. Lersten. Sieve tubes in vein endings of leaves revealed by a clearing technique.

\section{ABSTRACTS OF PAPERS}

RONI ALONI and ELIEZER F. INDIG, Department of Botany, Tel Aviv University, Tel Aviv 69978 , Israel. - The control of vessel diameter in the stem of Luffa.

The hypothesis that auxin controls the size and density of vessels along the plant axis was examined in the stem of Luffa cylindrica. The Luffa stem has a unique pattern of vascular bundles. In each internode there are ten bundles, three of which come from the leaf immediately above the internode and the rest descend from the younger leaves. Along each bundle there is a general basipetal increase in vessel diameter, from the young internodes towards the old ones. When the leaves were excised and were replaced by auxin, high auxin concentrations resulted in many narrow vessels, whereas low concentrations yielded few large vessels. The diameter of the induced vessels was found to increase in the root direction. These results support the Aloni and Zimmermann (1983) six-point hypothesis, that wide vessels are induced by low auxin concentrations while narrow vessels are a result of high concentrations.

RONI ALONI and TAL PLOTKIN, Department of Botany, Tel Aviv University, Tel Aviv 69978, Israel. - Vessel-length distribution in the stem of Coleus.

Vessel-length distribution and vessel width were studied in the stem of Coleus blumei Bth. by a latex-paint perfusion method combined with clearing. Longest vessel length was 18.7 $\mathrm{cm}$. The longest vessels were built up of 450
550 vessel elements. The vessel system was found to be organised in a segmented structure in which the longest vessels extended over three internodes. A basipetal increase in the inside vessel diameter was found along a vessel in the young internodes, where the upper parts of a vessel were narrow $(30 \mu \mathrm{m})$ and the lower parts were wide $(60 \mu \mathrm{m})$. From a functional point of view, the relatively wide and short vessels in Coleus combined high efficiency with safety (in terms of cavitation). Increase in vessel diameter increases efficiency of water conduction and the decrease in vessel length increases safety.

PIETER BAAS, Rijksherbarium, P.O. Box 9514 , 2300 RA Leiden, The Netherlands. - Ecological wood anatomy of trees and shrubs from Israel and adjacent regions.

The woody dicotyledons of Israel and adjacent regions (163 species) were studied to establish a means of identification of woods from the regions (A. Fahn, E. Werker, P. Baas: Wood structure and identification of trees and shrubs from Israel and adjacent regions. Israel Academy of Sciences, in the press). The data base was also used for the analysis of any ecological trends. Fusiform element length decreased consistently with increasing aridity; many species from arid habitats showed two vessel size classes as a presumed adaptation to both safe and efficient xylem sap conduction; other species from extremely xeric localities showed very narrow vessels only (emphasis on safety); yet 
another category of desert plants growing in wadis or near oases showed very wide vessels (emphasis on efficiency); scalariform perforations are very rare in the woody flora of Israel and completely absent from the desert flora; fibre-tracheids are most common in the Mediterranean maquis; the incidence of fusiform parenchyma, storied structure and included phloem appeared to be highest in the desert flora. These ecological trends partly conform to general trends of presumed adaptive significance, partly the trends in the woods from Israel can be explained by the floristic composition of the individual florulas and by the limited wood anatomical ranges of the constituent taxa.

SHERWIN CARLQUIST, Rancho Santa Ana Botanic Garden, Claremont, California 91711 and Department of Biology, Pomona College, Claremont, California 91711, U.S.A. - Ecological wood anatomy of some southern California plants.

The southern California flora is surveyed with respect to wood features of woody plants, with selected representatives of its component genera studied in order to determine whether the wood structure reflects an adaptation for survival of the dry season in this Mediterraneantype climate, or whether other factors (e.g., restriction to riparian habitats, succulence, or other vegetative features) represent a prime adaptation with respect to water relations. For most species, the wood does reflect closely the ecological regime in which they live. Qualitative and quantitative observations are given to support this view, and a picture is presented of the way in which such features as growth rings, vessel abundance, vessel grouping, vascular tracheids, vasicentric tracheids, 'true' tracheids, vessel dimensions, and helical sculpture in vessels are represented in this flora. Comparison of xeric members of this flora to those of the world flora with respect to wood anatomy does show that wood anatomy does contain features of prime significance with respect to water relations of plants in this environment.

J. STEPHEN CASE, Department of Biology, University of North Carolina at Chapel Hill, Chapel Hill, NC 27514, U.S.A. - Photogrammetric measurement of branching structure in trees and umbels using a microcomputer.

Direct measurement of the length and angles of branches is a tedious process; in small structures such as umbels it may require destructive measurement, while in large structures such as trees it is physically difficult. I have put together a relatively inexpensive system which does branching measurements photographically, using a $35 \mathrm{~mm}$ camera, a digitising tablet, and a microcomputer. Two or more photographs of the specimen taken from different positions are digitised by hand using a hierarchical system to uniquely identify branch points; this information is then used by the computer to reconstruct the three-dimensioral coordinates of the branching points. These coordinates can then be used to generate angle and length information. The method will work in any situation where branch density does not obscure visibility; it is currently being used to compare umbel shape in four species of Oxypolis and to compare canopy branching in several hardwood tree species.

VERNON I. CHEADLE and JENNIFER A. THORSCH, Department of Biological Sciences, University of California, Santa Barbara, California 93116 , U.S.A. - Kinds of vessels in Eriocaulaceae.

Eriocaulaceae occur mostly in tropics and subtropics, especially in South America. The family has 1100-1200 spp., mostly in three (Eriocaulon, 400; Paepalanthus, 500; Syngonanthus, 200) of the 12 or 13 genera. Typical habitat is moist sandy or mucky soil, but some species occur on dry land or in water. Common habit is rosette, but some are scandent, a few even shrubby. We examined all available parts, except flowers, usually from herbarium sheets, of 67 species in all genera $(18,19$, and 9, respectively, in genera noted above), with some 20 duplicates. We used the value 0 for tracheids only and values $1-5$ for increasing specialisation of vessels from only scalariform perforation plates (1.0) to only simple plates (5.0). In the family as a whole, the late metaxylem has an average value of 4.14 for roots, of 3.89 for caudices, of 3.03 for inflorescence axes, and of 1.83 for leaves. The numbers for comparable organs in the genus Eriocaulon are 3.07, 2.68, 2.69 and 1.50 , respectively, in Paepalanthus $4.58,4.32,3.03,1.93$; and in Syngonanthus $4.72,4.33,3.62,2.30$. Data on two sets of comparisons:

$\begin{array}{lllll}\text { First set } & \text { root } & \begin{array}{r}\text { caudex } \\ \text { axfl. }\end{array} & \text { leaf } \\ \text { 8 spp.: aquatics } & & & & \\ \text { 6 spp.: dryish habitat } & 4.63 & 2.69 & 2.40 & 1.56 \\ \text { Second set } & 4.50 & 3.20 & 1.55 \\ \text { 8 spp.: cushion-like habit } & 4.30 & 3.83 & 2.79 & 2.06 \\ \text { 3 spp.: shrubby habit } & 4.83 & 5.00 & 4.00 & 3.17\end{array}$

The data support the general conclusion that vessels occur throughout the late metaxylem of the plant, but are least specialised in the leaves and most specialised in the roots. Vessels in some caudices (or rhizomes) are exceptions. 
DARLEEN A. DEMASON and MARK A WILSON, Department of Botany and Plant Sciences, University of California, Riverside, California 92521 , U.S.A. - The continuity of primary and secondary growth in Cordyline terminalis (Agavaceae).

The primary thickening meristem (PTM) is continuous with the secondary thickening meristem (STM) in vegetative renewal shoots of Cordyline terminalis (L.) Kunth. This can be observed in longitudinal and transverse sections stained with safranin and fast green, analine blue-black or Azure B. The PTM is a wide zone in the crown, and initial cells are arranged in anticlinal files which are continuous from an area within the central cylinder to the outer cortex. The STM is narrow in radial extent, and consists of initial cells which are arranged in short, anticlinal files. When vascular bundles are followed (and plotted) acropetally from serial transverse sections starting with groups of anastomosing secondary bundles, secondary bundles are continuous with both major and minor axial primary bundles. All sympodial bundles are collateral at their upper extremities (leaf traces), amphivasal in intermediate regions of the central cylinder, and secondary at their basal extremities. Procambial strands run along or within the thickening meristem at all levels of the stem. These observations lead us to believe that (1) the PTM and STM function as a single entity, and (2) the primary and secondary bundles describe a single, continuous vascular system.

DAVID R. DOBBINS and JACK B. FISHER, Department of Biological Sciences, Millersville University, Millersville, PA 17551, and Fairchild Tropical Garden, Miami, FL 33133, U.S.A. Regeneration after wounding in stems of lianas.

Anomalous secondary growth is characteristic of many lianas belonging to several different families of plants. Much of the previous work has dealt with descriptive anatomy of anomalous growth rather than discussion of a possible important developmental role for anomalous growth. Many growth patterns involve either phloem and/or parenchyma embedded within secondary xylem or the formation of accessory cambia which results in alternating cylinders of phloem and xylem. We hypothesise that segments of living tissue embedded deeply within the xylem provide a reservoir from which regeneration can take place when the stem is injured. Nineteen species from nine different families were girdled and allowed to regenerate for ten months. Anatomical analyses showed that indeed those liana stems having anomalous secondary growth regenerated better than those liana stems having typical secondary growth.
G.S. ELLMORE and F.W. EWERS, Department of Biology, Tufts University, Medford, MA 02155 and Department of Botany \& Plant Pathology, Michigan State University, East Lansing, MI 48824, U.S. A. - Hydraulic conductivity in trunk xylem of elm, Ulmus americana.

The consensus that most xylem transport in stems of ring-porous trees occurs in the outermost growth ring requires experimental support. Significance of this ring is challenged by workers who find tracer dyes appearing in 7 or 8 growth rings, rather than in just the outermost increment. We test the hypothesis that the outermost growth ring is of overriding significance in water transport through stems of Ulmus, a ring-porous tree. Gravity flow rates through girdled, and through intact (control) stem segments were calculated. Second, $.05 \%$ safranin was gravity-fed through girdled and intact segments, staining zones responsible for transport. Finally, stained areas were sectioned at $40 \mu \mathrm{m}$ to measure diameters of functioning vessels. This was used to calculate maximum theoretical volume flow through conducting vessels using the Poiseuille equation. Gravity flow rates through segments from which the outermost growth ring had been girdled away, fall to $5-8 \%$ of the rate found in intact controls. Dyed vessels appear in up to 5 growth rings. However, average diameter of functioning vessels in older wood is $45 \mu \mathrm{m}$, compared to $110 \mu \mathrm{m}$ in the outermost growth ring. Since functioning vessels of the outermost ring are 2.5 times wider than those of older wood, the outermost ring theoretically should be able to accommodate 39 times the flow volume $\left(2.5^{4}\right)$. Thus each of up to 4 older rings might contribute $2.6 \%$ of flow volume. Both theoretical and experimental evidence indicate that at least $90 \%$ of stem flow volume occurs through the outermost growth ring.

SAM K. ESSIAMAH, Institute of Forest Botany, University of Göttingen, Büsgenweg 2, 3400 Göttingen, F.R.G. - Water uptake in deciduous trees during winter and the role of conducting tissues by the reactivation in spring.

During winter to spring, deciduous trees lack any setup for transpiration, nevertheless their buds swell and increase in weight. It is known that vessels play an important role in spring reactivation and phloem also may be involved since buds fail to break when twigs are ringed. This study investigates water/nutrient translocation from winter till reactivation in spring of four North European tree species: maple (Acer pseudoplatanus L.), birch (Betula pendula Roth), beech (Fagus sylvatica L.), and ash (Fraxinus excelsior L.). Significant results on water trans- 
port show that a continuous increase of water movement occurs in all the trees as from the end of March. However, this sets in earlier in birch and maple than in beech. In ash the water uptake is delayed. Similar results were obtained with transpiration experiments. The delay of water conductance in ash is probably due to the fact that ring-porous species like ash and oak depend on new conducting tissues to replace the previous year's nonfunctioning xylem. Analysis of three cations in buds showed that magnesium remained constantly low while calcium gave high values from the beginning. Also, potassium concentration rose and its accumulation correlated with water content/dry weight increase during bud development. Potassium thus indicated an acropetal water/nutrient transport to the buds, since the spring sap showed the same tendency. Since the origin and pathway of the spring sap are still unknown, and since besides xylem and phloem no other conducting tissues exist, a cooperative participation of both conducting tissues is conceivable.

FRANK W. EWERS, Department of Botany \& Plant Pathology, Michigan State University, East Lansing, MI 48824, U.S.A. - Xylem structure and water conduction in conifers and lianas.

Coniferous trees and dicotyledonous lianas (woody vines) form interesting morphological contrasts in their xylem structure and function. Lianas have among the largest (up to 8 metres or more) and widest (up to $500 \mu \mathrm{m}$ ) vessels in the plant kingdom. In conifers the water transport occurs through tracheids, which are relatively inefficient in transport. We can compare disparate growth forms in terms of leaf-specific conductivity (LSC), which is hydraulic conductivity per surface area of leaves supplied by a stem. With rapid transpiration, LSC is inversely proportional to localised pressure potential gradients. LSC is equal to the Huber value (sapwood area per leaf area supplied) times the specific conductivity (hydraulic conductivity per sapwood area). Lianas are similar to conifers in having hydraulic constrictions (low LSC's) at branch junctions. However, lianas generally have greater LSC's and specific conductivities but lower Huber values than do conifers. The narrow but efficient stems of lianas are possible partly because lianas are not self-supporting; the mechanical requirements are reduced. Secondly, the wide and efficient vessels of lianas remain conductive for much longer than might be expected (two to several years, versus one year for similar wide vessels in dicots). We have generally found larger vessels to be more susceptible to freezing-induced embolism than are small ones. However, in lianas, root pressures might serve to refill cavitated vessels.

ARTHUR C. GIBSON, HOWARD W. CALKIN and PARK S. NOBEL, Department of Biology, University of California, Los Angeles, CA 90024 , U.S.A. - Hydraulic conductance and xylem structure in tracheid-bearing plants.

Our ability to interpret correctly the physiological and ecological significance of specific wood designs depends on a thorough understanding of the function of the cell types that compose each wood. For water conduits (vessels or tracheids), an appropriate parameter for precisely quantifying the ability to permit water movement is hydraulic conductance per unit length, which can be estimated by obtaining both the hydrostatic pressure drop and volumetric flow for a known set of conduits under steady-state conditions. For technical reasons, woods do not make ideal subjects for quantifying hydraulic conductance. To get around these difficulties, hydraulic conductances have been quantified for whole plants and plant parts that have little or no secondary growth. Studies on pteridophytes demonstrate that some tracheid-bearing ferns can have hydraulic conductances equal to or even greater than bracken (Pteridium), which has primitive vessel elements. Comparisons are being made between plants with different cellular features of the water conduits, such as length, diameter, shape, lateral-wall pitting, and end-wall characteristics, to quantify the effects of each of these on water flow.

MARTIN C. GOFFINET, ROBERT M. POOL and HARRIET D. HUBBARD, Department of Horticultural Sciences, N. Y. State Agricultural Experiment Station, Geneva, NY 14456, and Vineyard Laboratory, 412 East Main Street, Fredonia, NY 14063, U.S. A. - Xylem integration between the parent cane and its elongating shoot in 'Concord' grapevines (Vitis labruscana).

Count-node 3 of vertically hanging canes and their attached, elongating primary shoots, were collected from 'Concord' grapevines and serially sectioned at $1 / 2$ week intervals, from -2 to +1 weeks from bloom, to determine how vascular development of the cane/shoot juncture related to the force needed to break the juncture. Until 10 days before bloom there was little secondary tissue in the new shoot base and no new secondary tissue in the node of the cane. Thereafter, cane cambial activity resumed at the node and progressed downward and laterally in the vascular cylinder. Newly formed secondary xylem in the new shoot base lacked full fibre lignification until bloom and was thus 
only weakly integrated with the older secondary xylem of the node. Full integration was further hindered by the 'crotch angle' between cane and shoot and the forced reorientation of vasculature may have reduced strength. New vasculature also had to accommodate to traces to other components of the compound bud and to the dead embedded base of last year's precocious axillary shoot ('summer lateral'). The increasing number of expanding and maturing leaves on the new shoot presumably served as a stimulus to xylem production and lignification in the cane/shoot juncture.

NELS R. LERSTEN, Department of Botany, Iowa State University, Ames, IA 50011, U.S.A. - Sieve tubes in vein endings of leaves revealed by a clearing technique.

A century ago, Fischer showed that vein endings in dicots could have sieve tubes extending as far as the xylem (I call this a complete vein), or sieve tubes could end at various distances short of the xylem or be lacking entirely (my term for this is incomplete vein). He said that different species show different patterns of complete and incomplete veins. The few studies since have verified Fischer's generalisations, but it has not been possible so far to determine patterns of distribution of complete and incomplete veins because of the need to rely on laborious reconstruction from serial sections. A recent statistical study (Magendans, 1983), for example, used a sample of less than 70 vein endings. I have discovered that chlorazol black E, when used alone as a dense stain, renders sieve tubes visible in the smallest minor veins and vein endings of cleared leaves. In favourable material it is therefore possible to survey perhaps a thousand vein endings in less time than it takes to reconstruct one vein ending from serial sections. Other features, such as changes in shape (swellings, bendings, etc.) are difficult to interpret from serial sections, but are easily seen in clearings. Many details of vein ending anatomy are, of course, not resolvable in clearings, but it is now possible to provide quantitative answers to certain questions about the distribution of types of vein endings. Such studies are underway, particularly in the soybean and other legumes, but the emphasis here is to illustrate the variations in xylem/phloem relations in vein endings as seen in leaf clearings.

ANN M. LEWIS and MELVIN T. TYREE, Harvard University, Harvard Forest, Petersham, MA 01366, U.S.A. and Dept. of Botany, University of Toronto, Ontario M5S 1A1, Canada. - The relative susceptibility to embolism of larger vs. smaller tracheids in Thuja occidentalis.
For many years botanists have assumed that larger xylem conduits are more susceptible to embolism than smaller ones. Recent experiments have confirmed this. Using the pressure bomb and dye ascents, we show the relative water potentials at which the earlywood and latewood tracheids of Thuja occidentalis embolise. We also show that during tissue rehydration, embolised larger tracheids take significantly longer to refill than smaller ones and do so at higher water potentials. Thus we conclude that larger tracheids are more susceptible to water stress, not only because they embolise at higher water potentials, but also because they are more difficult to refill.

CADANCE A. LOWELL and TERRY W. LUCANSKY, Department of Fruit Crops, and Department of Botany, University of Florida, Gainesville, FL 32611, U.S.A. - Developmental anatomy of stems of Ipomoea quamoclit and Ipomoea hederifolia (Convolvulaceae).

Development of the stem vasculature of Ipomoea quamoclit $\mathrm{L}$. and I. hederifolia L. may be separated into five ontogenetic stages, namely: the bicollateral bundle stage, the cambium-like meristem stage, the normal cambial stage, the anomalous cambial stage and the supernumerary cambial stage. Primary vasculature of the stem in both species consists of bicollateral bundles. Within these bundles the external protophloem is separated from the protoxylem and internal phloem by a cambiumlike meristem and its derivatives. The activity of this meristem produces cylinders of external metaphloem and metaxylem. A cambium arises between the external phloem and primary $x y-$ lem and produces secondary phloem centrifugally and secondary xylem centripetally. Lobed, concentric and foraminate patterns of anomalous secondary growth then occur in the stems of both species. A lobed pattern develops as the cambium produces two bands of secondary phloem and two lobes of secondary xylem. A concentric pattern arises from the activity of a discontinuous supernumerary cambium that develops within the secondary phloem and an internal cambium that originates from parenchyma cells between the primary xylem and internal phloem. A foraminate pattern develops as included phloem forms within parenchymatous islands of the secondary xylem. Anatomical features of these twining vines may be correlated with their specialised growth habit.

DAVID C. MICHENER, Arnold Arboretum, Harvard University, Cambridge, MA 02138, U.S.A. - Wood anatomy of Californian Penstemon (Scrophulariaceae). 
The systematic, habit, and ecological range of diversity of woody Californian Penstemon Mitchell was sampled by means of 52 collections (21 species, 7 sections, 3 subgenera). Woods are specialised in that vessel elements are typically short and fibre-tracheids form the mechanical tissue. Woods are stereotyped except for the ray parenchyma. Rays are highly variable between taxa in size, abundance, and degree of differentiation from the background tissue. Vascular tracheids, although present, are not common (thus differing from the related genus, Keckiella Straw). Species of section Peltanthera have wood that is strikingly similar: the other species group poorly by taxonomic disposition. Vulnerability and mesomorphy scales rank the samples in relation to apparent drought severity.

REGIS B. MILLER, Center for Wood Anatomy Research, Forest Products Laboratory, P.O. Box 5130, Madison, WI 53705, U.S.A. - Sodium nitrite applied on the heartwood of oak (Quercus) separates the subgenus Lepidobalanus from Erythrobalanus.

Over 30 years ago Stearns discovered that a $10 \%$ solution of sodium nitrite reacts differently on the heartwood of commercially important U.S. species of red and white oak. Recently investigations on 1000's of specimens confirmed Stearns' findings, but no study has focused on all oaks. Based solely on the wood, three groups are recognised: red oaks (ringporous species of Erythrobalanus), white oaks (ring-porous species of Lepidobalanus), and live oaks (diffuse- and semi-ring-porous species). On white oak heartwood, the sodium nitrite solution eventually turns dark greenish or purplish brown to black; whereas on red oak, the colour is light yellowish or brown. I tested 714 specimens representing 39 species of white oak and 38 species of red oak throughout the world. Occasional discrepancies were checked anatomically and in all cases the sodium nitrite correctly distinguished between the distinctly ring-porous red and white oaks. On the live oaks, however, the test is variable. For example, 7 of 9 specimens of Quercus seemannii (Erythrobalanus) test like red oak. These occasional discrepancies could not be checked anatomically since there is no way to distinguish between the live oaks of Erythrobalanus and Lepidobalanus or the intermediate Protobalanus, and often it is difficult to determine if heartwood is present. Based on available data and general trends, however, I conclude that sodium nitrite not only separates the ring-porous red and white oaks, but also separates the live oaks into their proper subgenera with the exception of Protobalanus.
J. THOMAS QUIRK, Center for Wood Anatomy Research, Forest Products Laboratory, P.O. Box 5130, Madison, WI 53705, U.S. A. - Wood anatomy of Pterocarpus and Dalbergia.

The wood anatomy of 180 specimens of 19 species of Pterocarpus and 245 specimens of 65 species of Dalbergia was studied to determine whether the two genera can always be separated and if species or species groups can be identified within each genus. Pterocarpus has exclusively homocellular rays that are uniseriate and in part biseriate in a few species. Most species tend to be ring- or semi-ring-porous. Axial parenchyma is aliform-confluent and banded, but not reticulate and crystals commonly occur in slightly enlarged cells. Dalbergia has homo- to hetero-cellular rays that are mostly 2-3-seriate. Most species are diffuse-porous. Axial parenchyma is banded and in some species is reticulate and crystals seldom occur in slightly enlarged cells. Within Pterocarpus heartwood colour is a useful character to group species. Eight species have white to yellowish heartwood, and 11 species have yellow- or redbrown heartwood often with purple overtones which is frequently streaked. Within this latter group, 3 subgroups can be distinguished on the basis of alcohol extract colour and fluorescence and density. Within Dalbergia heartwood colour is also a useful character to group species. Thirty species have whitish to yellowish heartwood and 35 species have yellow- or redbrown heartwood often with purplish overtones which is often streaked. Within both major groups additional segregates are possible using reticulate parenchyma, shape of marginal ray cells (square and/or upright), ring porosity, white deposits in vessels, alcohol extract colour and fluorescence, maximum tangential vessel diameter, and density.

PAUL M. RICH, Biological Laboratories, Harvard University, 16 Divinity Avenue, Cambridge, MA 02138, U.S.A. - Developmental anatomy of the stem in Welfia georgii Wendl. ex Burret, Iriartea gigantea Wendl. ex Burret, and other arboreal rainforest palms: implications for mechanical support.

Changes in stem anatomy with radial position and height were studied in the arboreal rainforest palms Welfia georgii Wendl. ex Burret, Iriartea gigantea Wendl. ex Burret, Socratea durissima (Oerst.) Wendl., Euterpe macrospadix Oerst., Prestoea decurrens (Wendl.) Moore, and Cryosophila albida Bartlett. Vascular bundles are concentrated toward the stem periphery and peripheral bundles contain more fibres than central bundles. Expansion and lignification of fibres within vascular bundles continues 
throughout the life of a palm, even in the oldest tissue. Within individual vascular bundles, the fibres nearest the phloem expand first and become heavily lignified. A front of expanding fibres moves outward from the phloem until all fibres within a vascular bundle are fully expanded and lignified. Peripheral vascular bundles differentiate first and inner bundles later. In stem beneath the stem crown, individual vascular bundles increase in diameter by more than two-fold in Welfia georgii and by more than four-fold in Iriartea gigantea. Ground tissue cells elongate to accommodate expanding vascular bundles and become lignified to a lesser degree than fibres. Sustained cell expansion results in limited, but significant increases in stem diameter. Sustained lignification results in dramatic increases in stem stiffness and strength.

JOHN S. SPERRY, Harvard University, Harvard Forest, Petersham, MA 01366, U.S. A. - Xylem embolism in the palm Rhapis excelsa.

This investigation evaluates how palms, which lack secondary growth and cannot continually produce new xylem, are able to cope with $x y-$ lem failure via embolism. Rhapis was chosen for the study because of its availability, convenient size, and well-known vascular system. Embolism was detected using xylem flow resistance measurements on excised axes: a decrease in resistance after the removal of flow-impeding embolisms by a pressure treatment indicates their previous presence in the axis. There are at least four ways in which Rhapis accommodates xylem failure via embolism. 1) Laboratory studies show that in stems and petioles, xylem pressures must drop below c. $-3.0 \mathrm{MPa}$ before flow is significantly impeded by embolism. In the field, pressures reach these levels only during dry periods. 2) When pressures do reach embolism-inducing levels, they do so in the leaf, while the stem remains at moderate pressures. Embolism is confined to the expendable leaf xylem, and stem xylem remains functional. The large difference in pressure between stem and leaf xylem is primarily due to the hydraulic architecture of the shoot: the steepest pressure gradients are in the lamina, and the stem-to-leaf connection. 3) Stomatal closure occurs at leaf water potentials of -3.0 to $-3.6 \mathrm{MPa}$. For this reason, excessive embolism is avoided in the leaf, and embolism-inducing pressures are not likely to reach the stem. 4) Evidence indicates embolised vessels are refilled during prolonged rainfall. In the laboratory, embolisms dissolve within 5 hours at ambient pressure, and in the field xylem pressures reach ambient levels during extended rain.
P. BARRY TOMLINSON, Harvard University, Harvard Forest, Petersham, MA 01366, U.S.A. - Development of the leaf trace system within individual leaves of the palm Rhapis excelsa.

Leaf traces that connect to the central cylinder, number about 100 and constitute the main vascular supply, as indicated by the number of protoxylem elements. Leaf traces that connect to the cortex are much more numerous (about $1,000)$ but are insignificant in terms of vascular supply. Development of the vascular system in relation to the position of the leaf in the crown closely follows the changing physiological status of the leaf as it matures (observations of John Sperry). Since vascular connections between leaf and stem are continually made over many plastochrons the tangential and radial coordinates of bundles changes. In particular younger bundles can be inserted between existing bundles. Although a self-repeating process of vascular connection is present the topographic status of a bundle is determined by the amount of crown expansion before and after stem-leaf linkage. Unlike dicotyledons there is no simple relation between vasculature and phyllotaxis because axial bundles, organised within the meristematic cap, themselves have a helical path, similar in direction to, but different in magnitude from, the helical phyllotaxis. Monocotyledons continue to confound speculative generalisations about vascular organisation in seed plants.

ROBERT D. WARMBRODT, Department of Horticulture, University of Maryland, College Park, MD 20742, and USDA Plant Photobiology Laboratory, Beltsville, MD 20705, U.S.A. Solute concentration in the phloem and associated vascular and ground tissues of the root of Hordeum vulgare $\mathbf{L}$.

Plasmolytic studies utilising a graded series of mannitol solutions $(0.1-1.4 \mathrm{M}$ in $0.1 \mathrm{M}$ increments) on adventitious roots of 3-week-old plants of Hordeum vulgare L. var. Barsoy, indicated that a positive concentration gradient occurs from the companion-cell-sieve-tube complexes to the parenchyma cells of the cortex in this organ. In tissue taken $5 \mathrm{~cm}$ from the root tip, the $\mathrm{C}_{50}$, that is, the estimated mannitol concentration plasmolysing, on the average, $50 \%$ of a given cell type, was $1.1 \mathrm{M}$ for both proto- and metaphloem sieve-tube members. The companion cells had a $\mathrm{C}_{50}$ similar to that of the sieve elements. The $\mathrm{C}_{50}$ for xylem parenchyma and pericycle cells was $0.7 \mathrm{M}$ while the cells of the endodermis and cortex plasmolysed in the lowest concentration of mannitol $(0.4 \mathrm{M})$ of any cell type of the root. The results suggest that phloem unloading and organic solute transport in the root of barley may be symplastic. 
E.A. WHEELER, R.G. PEARSON, C.A. LAPASHA, C.W. HATLEY, T. ZACK and A. SMITH, Department of Wood and Paper Science, North Carolina State University, Raleigh, NC 276958005 , U.S. A. - Computer-assisted wood identification based on perforated card keys.

For wood identification, multiple entry keys using marginally perforated cards have long been an alternative to dichotomous keys. Data on wood structure were recorded on such cards at various institutions such as the Commonwealth Forestry Institute, Oxford; Princes Risborough Laboratory, and Centre Technique Forestier Tropical. Card sorting by needle is a slow process. An obvious alternative is to computerise the data and use a computer to sort through them. In 1978, we computerised the original Oxford/PRL data and developed a search program written in PL/ 1 for use with a mainframe computer. More recently, we have made additional entries based on recent literature and added 'information qualifiers'. Now there are databases for 1) dicotyledonous species (approx. 4000 entries), 2) families, 3) conifers, and 4) 'hardwood fibres'. Also, the search program has been rewritten into PASCAL for use with microcomputers (both APPLE Ile and IBM-PC). The microcomputer versions of the search program have a menu-option, and it is possible to get a short textual description of a suggested match which lists the features recorded present in that entry. These databases and the search program are a helpful tool in 'routine' wood identification and in teaching.

GEORGE J. WILDER, Biology Department, Cleveland State University, Cleveland, Ohio 44115 , U.S.A. - Stelar anatomy of first-order roots in the Cyclanthaceae (Monocotyledoneae),

In the steles of cyclanthaceous first-order roots the xylem always develops within xylem fascicles, and the phloem either comprises phloem fascicles or is dispersed. Xylem and phloem fascicles may be encircled by a sheath of cells different from cells of the interfascicular tissue. The interfascicular tissue is either homogeneous, i.e., comprised of fibres, or heterogeneous, i.e., formed of fibre aggregates and a parenchymatous and/or sclerenchymatous intrusive network. This network is interpreted as modified pith. A true pith is often present, and four kinds of true pith are recognised.

M. WISNIEWSKI and E. ASHWORTH, USDA/ ARS, Kearneysville, WV 25430 , U.S.A. - Ultrastructural changes related to cold hardiness in cortical and xylem parenchyma cells of Prunus persica.
Woody plants respond to freezing stress by extracellular freezing or by supercooling. In the former, the plasmalemma plays a major role in freezing resistance while in the latter it plays only a minor role. Published reports have associated seasonal changes in cells that undergo extracellular freezing with acclimation and deacclimation. We have extended these observations to tissues with cells that exhibit both extracellular freezing (cortical cells) and deep supercooling (xylem parenchyma). Current year shoots were collected from fall, 1983 through summer, 1984 and prepared for TEM. Our observations of cortical cells agree with previous reports. During acclimation, the large, central vacuole was slowly broken up into many smaller vacuoles. At the height of acclimation, vacuoles were infrequent and chloroplasts enlarged. Invaginations of the plasmalemma and vesicle formation were not as marked as described for other species. During deacclimation, cells reverted to their preacclimation appearance. Surprisingly, in xylem parenchyma the most marked change was in the conformation of the plasmalemma. During acclimation, there were marked invaginations containing vesicle-like components and fibrillar wall material. These invaginations were pinched off into the cytoplasm and engulfed in vacuoles suggesting wall and membrane turnover. At the height of acclimation, the plasmalemma appeared smooth with only minor invaginations. During deacclimation invaginations reappeared. Observations of membrane turnover during acclimation may represent changes in lipid composition that would impart greater fluidity to the membrane.

BEATA ZAGÓRSKA-MAREK, Harvard University, Cabot Foundation, Petersham, Mass. 01366, U.S.A. (Permanent address: Wroclaw University, Botanical Institute, Kanonia St. 6/8, 50-328 Wroclaw, Poland.) - Domain dislocations in cambium of Fraxinus excelsior.

In Fraxinus, cambial domains are short $(2-3$ $\mathrm{mm}$ ) and characteristically perpendicular to the stem axis. They move slowly upward resulting in wavy wood formation. At some locations in the cambial surface, transverse bifurcations of domains occur. They resemble edge dislocation in the molecular networks of crystals. The point of bifurcation does not shift horizontally but moves vertically with the same velocity as the domain pattern itself. During the study (c. 30 years) particular dislocations did not show any significant changes in their dimensions and configuration. Dislocations and their persistence are important to understanding the nature of the domain pattern which is an example of morphogenetic fields in plant tissues. 